\title{
Development of an Automatic Packer Using Vacuum Packaging and its Effects on the Rice Quality
}

\author{
T. Y. Yan, J. H. Chung and C. O. Rhee
}

\begin{abstract}
적 요
본 연구에서는 배아미, 현미, 가능성쌀들 및 진공을 요하는 식품의 품질을 보존하기 위해서 연속식 자동진공포장기 를 국내 최초로 개발하였다. 배아미의 진공포장 성공률은 $92.6 \%$ 이었고 실패율 $7.4 \%$ 에서 진공포장기 자체에서 불완전 테이평의 밀봉작업으로 진공이 서서히 풀리는 경우가 $5.5 \%$ 그리고 진공하기 전 자동비닐포장기에서 포장시 봉지 윗부 분 밀봉이 불완전해 $1.9 \%$ 가 진공이 풀렸다. 이에 개발한 자동진공포장기의 진공포장성공률은 약 $94.5 \%$ 수준이었다. 진 공포장기로 진공시간에 따른 진공압력을 측정하였고 배아미 $2,3,5 \mathrm{~kg}$ 를 진공포장하는데 소요되는 시간은 각각 6,8 , 11 초이었다. 진공포장으로 처리한 배아미와 진공포장 처리하지 않은 배아미를 각각 3 개월간 저장실험하여 백도 함수 율, 과산화물가, 산가를 저장기간별로 분석하였다. 그 결과, 백도는 진공처리가 2 감소, 비처리가 4 감소하였고, 함수율 은 진공처리가 $0.8 \%$ 감소, 비처리가 $1.3 \%$ 감소, 과산화물가는 진공처리가 최대 $1.89 \mathrm{meq} / \mathrm{kg}$ 까지 서서히 증가하였고 비 처리가 $3.45 \mathrm{meg} / \mathrm{kg}$ 까지 급속히 증가하였다가 서서히 감소하였다. 산가 역시 진공처리가 최대 $0.71 \mathrm{mg} / \mathrm{g}$ 까지 서서히 증 가하였고, 비처리의 경우는 $0.98 \mathrm{mg} / \mathrm{g}$ 까지 급속히 증가하였다. 그리고 현미의 진공포장에서도 산가 및 과산화물가 변화 가 배아미 경우와 비슷하였다. 또한 진공포장 제품에 인위적으로 쌀벌레들을 넣은 경우 15 일 지나면 산소부족으로 모 두 사멸하였다. 따라서 개발한 진공포장기로 진공포장한 경우 배아미 및 현미의 품질을 잘 보존할 수 있었다.
\end{abstract}

Keywords : Packer, Vacuum packaging, White embryo rice, Moisture content.

\section{INTRODUCTION}

High quality rice should be produced to make native agricultural industry more competitive and to satisfy the consumers' demands. Recently, several kinds of specialized rice products, such as white rice with embryo, germinated brown rice, the pre-washed white rice that can be cooked without washing, the rice fortified with other nutrients, and functional rice are produced and sold in some supermarkets in Korea. Rice in storage respires while consuming nourishment. As white rice with embryo has more nutrients, enzymes, and fibers than normal white rice (Houston, 1972), many consumers are attracted by white rice with embryo in market surveys. However, the embryos of white rice are easily deteriorated due to high temperature in hot seasons. Even mildews and insects are sometimes found in white rice. Non-vacuum packaging not only shortens the shelf life of rice products but also depreciates the rice quality because chemical components such as carbohydrate and fat in rice are dissolved and oxidized, and consequently free fatty acid and various organic acids are generated during the storage period. It is widely known that vacuum packaging can prolong the shelf life of agricultural products and maintain their quality and freshness because it can attenuate their biological respiration rate(Hosokawa et al., 1995 and Murcia et al., 2003).

The prevention of insect pests in rice products is one of the important factors for the production of high quality rice. Stored-product insects, which outbreak in high tem-

This study was conducted by the research fund supported by Agricultural R\&D Promotion Center and Sejin Teck Co. Ltd. The authors are Jong Hoon Chung, Professor, T. Y. Yan, Graduate Student, Dept. of Biosystems and Agricultural Engineering, C. O. Rhee, Professor, Department of Food Science and Technology, Inst. of Ag. Sci. and Tech. Chonnam National University, Gwangiu, Korea.

Corresponding author; J. H. Chung, Professor, Dept. of Biosystems and Agricultural Engineering, Inst. of Ag. Sci. and Tech. Chonnam National University, Gwangiu, 500-757, Korea; Fax: +82-62-530-2156; e-mail: 〈jhchung@chonnam.ac.kr 〉. 
perature and humidity, are usually found in rice products. They are Indian meal moth(larval period), lesser grain borer, and rice weevil. Vacuum packaging is one of the effective physical methods of insect control. Dendy and Elkington studied that the lack of oxygen in hermetic storage was the major cause of insect death(Calderon \& Barkai-Golan, 1990).

At present, semi-automatic vacuum packers of chamber type and nozzle type are mainly used by rice processing complexes(RPC). These are also not continuous type with low processing capacity. Therefore, it is necessary to develop an automatic vacuum packer of continuous type with a high processing capacity to improve the productivity of Korean RPCs.

In this study, an automatic vacuum packer designed with functional virtual prototyping technology(Yan et al., 2003 and Erdman et al., 2001) to prolong the shelf life of white rice with embryo was manufactured and evaluated. The specific objectives of this research were to: 1 . develop an automatic vacuum packer of continuous type; 2 . evaluating the performance of the vacuum packer; 3. analyze the relationship between vacuum time and vacuum level at different pouch sizes; 4 . investigate the preservation effects of vacuum packaging on white rice with embryo in physical and chemical changes.

\section{MATERIALS AND METHODS}

\section{A. Development of a vacuum packer}

The functions of the proposed vacuum packer were to remove the air from a pouch of rice through a needle in a short time and to seal the vacuum hole quickly with a piece of transparent tape. The vacuum packer(Fig. 1) consisted of the following three modules was designed and manufactured: (1) the pressing board module that accelerates the air removing process; (2) the vibrating conveyor module that shapes the vacuum-packed rice products. (3) the tape adhering module that puts a transparent tape piece $(5 \times$ $3 \mathrm{~mm}^{2}$ ) on a pouch. All the moving parts of the vacuum packer were operated according to the developed control algorithm(Fig. 2) of a programmable logical controller(PLS). The conceptual operating sequences for the vacuum packer as shown in Fig. 3 were developed. The vacuum packer was designed to pack the cereal products in various sizes and in different vacuum levels depending on vacuum time, shape-forming time, vibrating-time, and the intended position of the vacuum-hole on a pouch.

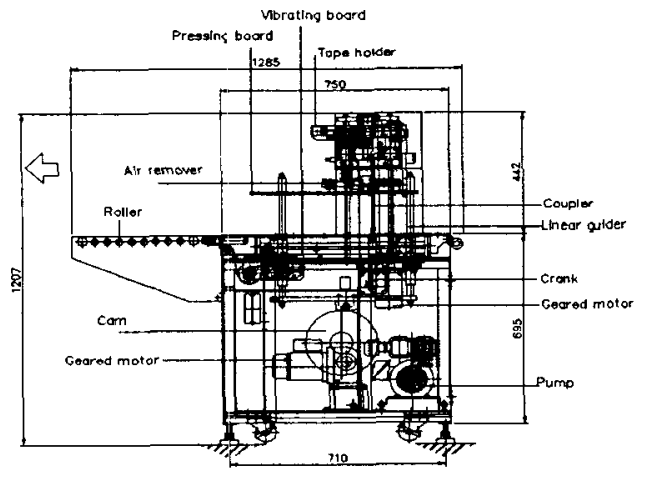

Fig. 1 The configuration of the developed automatic vacuum packer.

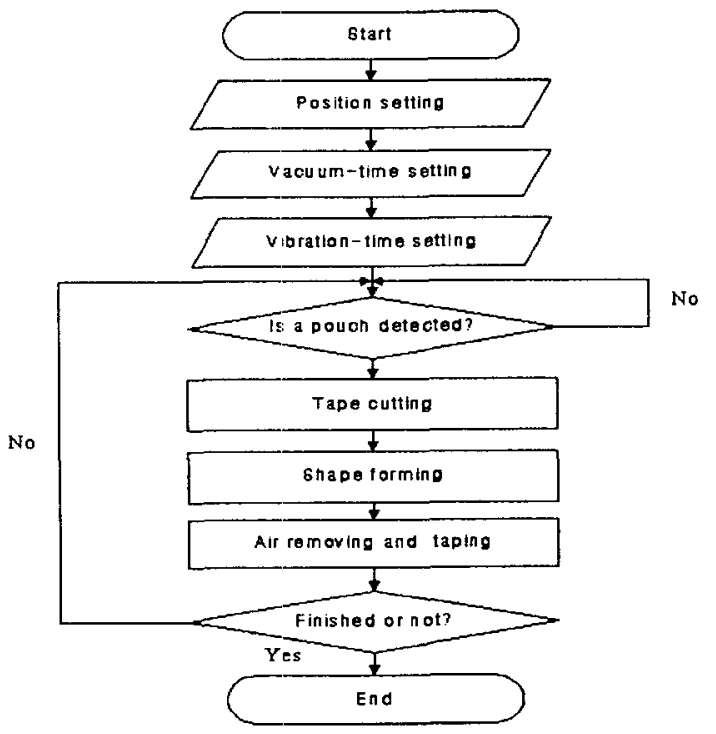

Fig. 2 Control algorithm of the developed automatic vacuum packer.

\section{1) Pressing board module}

The pressing board module was operated with a camfollower mechanism shown in Fig. 4. The follower of cam mechanism adopted a roller-type. It was driven by a 0.1 


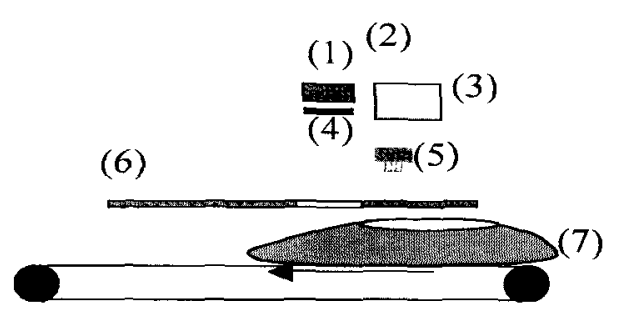

(a) Tape cutting and positioning a pouch

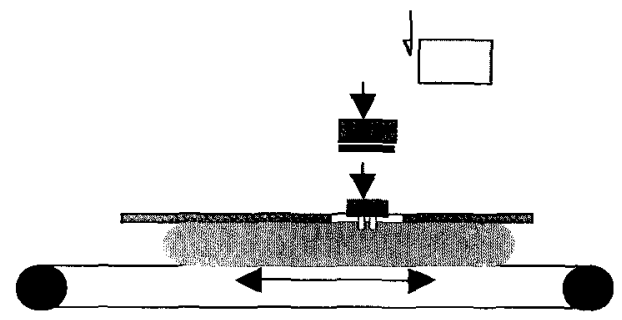

(c) Vibrating a pouch and air removing

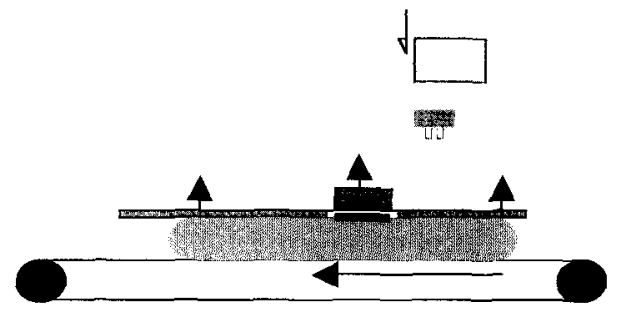

(e) Releasing a pouch

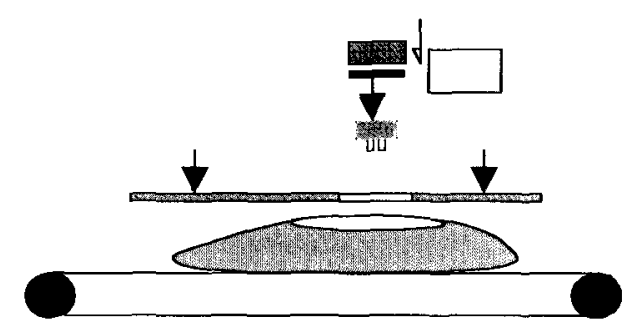

(b) Pressing a pouch

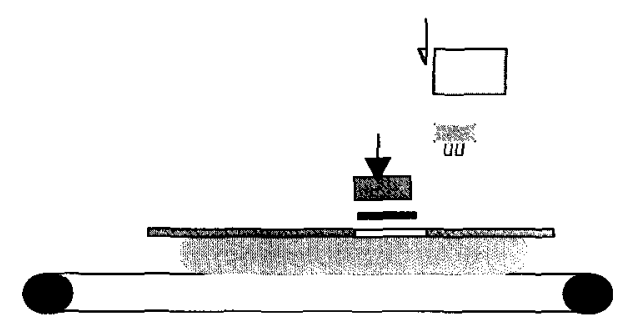

(d) Taping a pouch

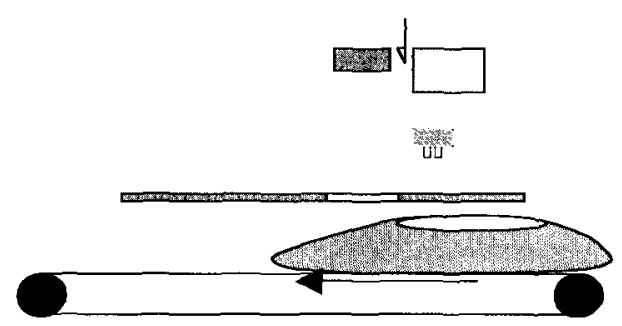

(f) Restart from a) step

Fig. 3 Conceptual view of the operational sequences of the vacuum packer ; (1) tape holder ; (2) cutter; (3) tape feeder ; (4) tape ; (5) air remover of needle type ; (6) pressing board ; (7) pouch.

$\mathrm{kW}$ geared-motor with a reduction rate of $1: 25$ (Model GM-H2B-RL, Mitsubishi Co., Japan). The cam was offset with the output shaft of a motor. As the shaft of the geared motor rotates, the pressing board undergoes a vertical translational motion. When the thickness of a pouch was too large, the cam and the follower were disconnected each other to fit in different sized pouches. The 550 by $280 \mathrm{~mm}$ rectangular pressing board was utilized to accelerate the air removing speed. A rubber plate of $3 \mathrm{~mm}$ in thickness with the same shape was glued underneath the pressing board to protect the packaging film of a pouch during the vibrating process for shape forming. The pressing board was screwed onto two supports that mounted on two $522 \mathrm{~mm}$ linear motion guides.

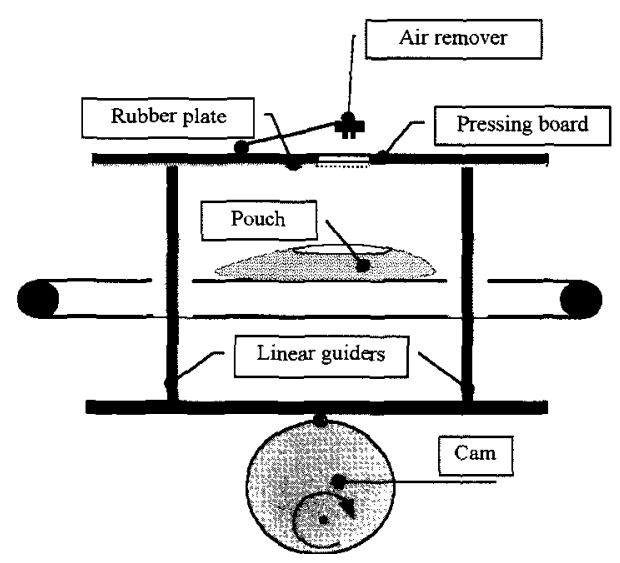

Fig. 4 Schematic view of the pressing board module.

\section{2) Vibrating conveyor module}

A vibrating conveyor(Fig. 5) mounted on two linear guides was used to make the vacuum-packed rice in shape 
for its commercial value. The air in the pouch was removed using a needie during the vibrating. The vibrating conveyor module also adopted cam-follower mechanism with the eccentricity of $1 \mathrm{~mm}$. An induction motor(Model 51K91A-SF90, Oriental Motor Co., Japan) was used to drive the vibrating board module. Another geared motor with a reduction rate of $1: 10$ (Model GM JB, Mitsubishi Co., Japan) was used to drive the belt conveyor for transferring pouches to a proper position. As soon as a pouch was positioned properly, the motor for driving the vibrating board started to shape the pouch on the belt for a set time.

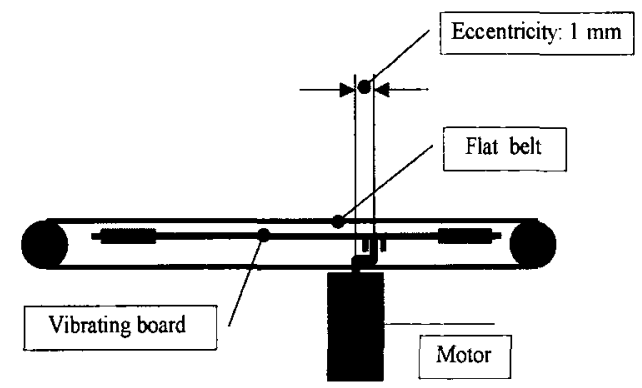

Fig. 5 Schematic view of the vibrating board module.

\section{3) Tape adhering module}

The tape adhering module had slider-crank mechanism. The schematic view of this mechanism is shown in Fig. 6. The tape adhering module consisted of a tape holder containing 24 tiny holes of $1 \mathrm{~mm}$ in diameter, a $170 \mathrm{~mm}$ long crank, a $300 \mathrm{~mm}$ long coupler, and a $25 \mathrm{~W}$ gearedmotor with the reduction rate of $1: 50$ (Model GM-JB, Mitsubishi Co., Japan). The crank was pivoted to the shaft of the motor. The coupler was pivoted to the crank and the tape holder through two revolute joints. The tape holder was mounted on two linear guides through two prismatic joints. As the motor shaft rotates, the tape holder performs an up-down linear movement for tape adhering. When a rice pouch is too thick, then the tape holder can be separated into two parts to adjust it to different sized pouches. As a flexible plastic hose was used to connect the tape holder to a vacuum pump(Model KRX3-SS-4001-G3, Orion Machinery Co., Japan) through a solenoid valve, the tape holder could tightly hold a piece of transparent tape supplied by an electronic tape dispenser during a taping operation.

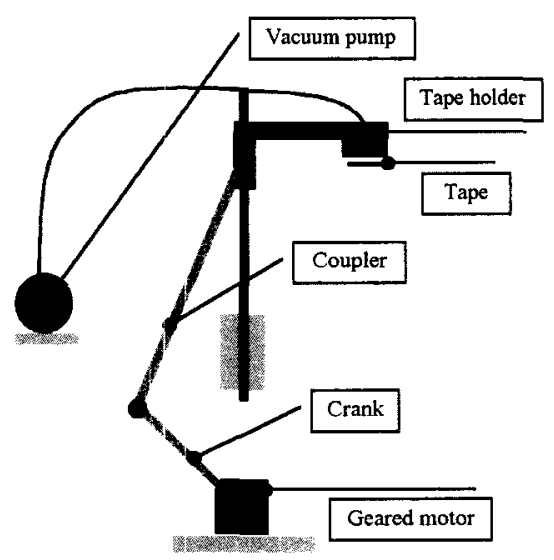

Fig. 6 Schematic view of the tape adhering module.

\section{B. Performance experiments}

Paddy(Rice variety: Dongjinbyeo) freshly harvested in September 2001 was bought from JinWon Agricultural Union, Chonnam Province. The paddy was processed into white rice embryo at the mill of Chonnam National University and was used as experimental material. The white rice with embryo had embryo adherence rate of $52 \%$ and moisture content of $16.1 \%$ (w.b.). The rice was pre- packaged in $5 \mathrm{~kg}$ pouches with the laminated film of nylon $(15 \mu$ $\mathrm{m})$ /polyethylene $(95 \mu \mathrm{m})$ using an automatic vinyl packer(SP-10, Sejin Tech Co. LTD, Korea). Two main physical properties of the film are as follows: oxygen transmission rate(OTR) is $52.6 \mathrm{cc} / \mathrm{m}^{2}$; water vapor transmission rate(WVTR) is $260 \mathrm{~g} / \mathrm{m}^{2}$. The pre- packaged pouches were then vacuum-packed using the developed automatic vacuum packer. One hundred and eight pouches of vacuum-packed pouches of the white rice with embryo were produced to investigate the performance of the vacuum packer. The pouches were stored for 24 hours for discriminating the pouches that were unsuccessfully packaged by the vacuum packer. Eight successfully vacuum-packed pouches and one non-vacuum-packed pouch were randomly chosen and stored at room temperature $\left(20 \sim 27^{\circ} \mathrm{C}\right)$ to investigate the effects of vacuum packaging on the moisture content, whiteness, peroxide value, and acid value of white 
rice with embryo.

In addition to the white rice with embryo, the identical batches of experimental treatments have been applied with brown rice to confirm the preservation effects of the vacuum packaging considering the fact that brown rice deteriorates more quickly during hot seasons.

Except for the pouches mentioned above, additional five vacuum-packed pouches of white rice with embryo infested by the three kinds of insects were chosen for an insect control experiment to evaluate the effect of vacuum packaging on insect control. The habituating insects in each pouch were counted before the storage as ranged from 5 to 20 .

The developed vacuum packer was tested to pack the pouches of $2 \mathrm{~kg}$ (Pouch size: 25 by $30 \mathrm{~cm}$ ), 3kg(Pouch size: 30 by $35 \mathrm{~cm}$ ), and $5 \mathrm{~kg}$ (Pouch size: 30 by $45 \mathrm{~cm}$ ). The relationship between vacuum level and vacuum time at the different pouches was investigated to improve the productivity and efficiency of the vacuum packer.

\section{1) Measurement of vacuum level}

A digital vacuum gauge(Model KVC-700, range 1-1500 Torr, KVC Instruments Co., LTD, Korea) with \pm 0.1 Torr accuracy was used to measure the vacuum level in a pouch. The digital vacuum gauge consisted of a 16-bit analog to digital converter, a sensor of diaphragm type, a 4 bit digital displayer, and a needle. A piece of 5 by 5 by $0.5 \mathrm{~cm}$ rubber plate was attached on the pouch to be measured to prevent air leakage during measurement as shown in Fig. 7.

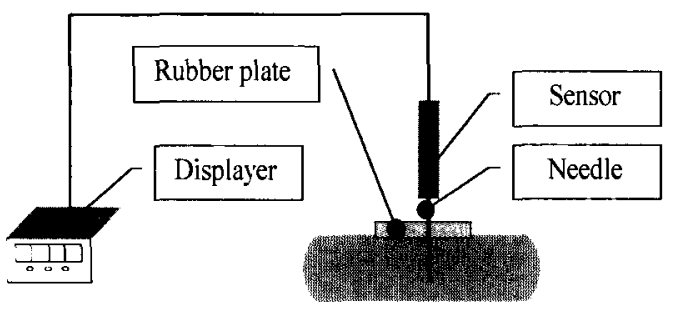

Fig. 7 The measurement of the vacuum level in a pouch.

\section{2) Measurement of whiteness}

The whiteness of the white rice with embryo for the storage experiment was measured using a whiteness meter
(Model C-300-3, Kett Electric Laboratory, Japan). Before each measurement, the whiteness meter was calibrated using a standard whiteness disk provided by the manufacturer.

\section{3) Measurement of peroxide value}

The peroxide value is a common measure that indicates the degree of oxidation of the white rice with embryo, i.e. the amount of peroxides in the white rice with embryo by determining the milliequivalents(meq) of active oxygen per kilogram of fat. The peroxide value was determined using the method of AOCS Cd 8-53(1973). The method involves an extraction of the fat phase from the white rice with embryo using chloroform. The procedures of the method used in this study were as follows: (1) A sample was grinded using a mill, and $3.0 \mathrm{~g}$ of the sample was put into an erlenmeyer flask and then $10 \mathrm{ml}$ chloroform was added into the flask; (2) extracting peroxides: $15 \mathrm{ml}$ of acetic acid and $1 \mathrm{ml}$ saturated potassium iodide (KI) solution were added into the flask, and it was shaken for one minute with a shaker, then kept it in the dark for 5 minutes; (3) titrating and determining the peroxide value: the solution was titrated with $0.01 \quad \mathrm{~N} \mathrm{Na}_{2} \mathrm{~S}_{2} \mathrm{O}_{3}$. The end-point was determined when the mixture turned colorless. The peroxide value was determined by eq. (1).

$$
P_{v}=\frac{\left(T_{1}-T_{0}\right) \times f \times 0.01}{S} \times 1000
$$

where $P_{v}$ is the peroxide value $($ meq $/ \mathrm{kg}), T_{1}$ is the titration value of $0.01 \mathrm{~N} \mathrm{Na}_{2} \mathrm{~S}_{2} \mathrm{O}_{3}, \mathrm{~T}_{0}$ is the titration value of blank test, $\mathrm{S}$ is the mass of sample $(\mathrm{kg}), \mathrm{f}$ is the normality of $0.01 \mathrm{~N} \mathrm{Na}_{2} \mathrm{~S}_{2} \mathrm{O}_{3}, 0.01$ is the equivalent amount of peroxide in $1 \mathrm{ml}$ of $0.01 \mathrm{~N} \mathrm{Na}_{2} \mathrm{~S}_{2} \mathrm{O}_{3}$.

\section{4) Measurement of acid value}

The acid value is the amount of free acid present in fat as measured by the milligrams of potassium hydroxide needed to neutralize it. The acid value was assayed by the method of AOCS Cd 3a-63(1973). The procedures of the method used in this study were as follows: (1) A sample was grinded using a mill, and $5 \mathrm{~g}$ of the powdered rice sample was measured, and then it was put into an Erlenmeyer flask; 
Development of an Automatic Packer Using Vacuum Packaging and its Effects on the Rice Quality

(2) $100 \mathrm{ml}$ diethyl ether-ethanol mixture solution $(2: 1)$ was added into the flask; (3) the mixture was shaken in a shaking incubator $\left(25^{\circ} \mathrm{C}, 200 \mathrm{rpm}\right)$ for 3 hours. The indicator of this experiment was $1 \%$ phenolphthalein. The solution was titrated with a $0.1 \mathrm{~N} \mathrm{KOH}$-ethanol. The end-point was determined when the mixture stayed pink for 30 seconds. The acid value was calculated using eq. (2).

$$
A_{v}=\frac{5,611 \times(A-B) \times N}{S}
$$

where $A_{v}$ is the acid value(mg/g), $S$ is the weight of the sample(g), $A$ is the volume of $0.1 \mathrm{~N} \mathrm{KOH}$ used in titration $(\mathrm{ml}), \mathrm{B}$ is the volume of $0.1 \mathrm{~N} \mathrm{KOH}$ used in titrating the blank(ml), and $\mathrm{N}$ is the normality of $0.1 \mathrm{~N} \mathrm{KOH}$.

\section{5) Measurement of moisture content}

The moisture content of the white rice is considered as a factor that directly related to the taste of cooked rice. The change of moisture content of the vacuum-packed white rice with embryo was investigated during the storage period. A moisture meter(Riceter K305, Kett Electric Laboratory, Japan) with an accuracy of $\pm 0.1 \%$, was used for measuring the moisture content.

\section{6) Statistical analysis}

In this study, statistical analysis was performed using two-way analysis of variance. The measurements of all quality parameters were made in triplicate and were expressed as mean \pm standard error. The criterion for significance was $\mathrm{P}<0.05$.

\section{RESULTS AND DISCUSSION}

\section{A. Development of the automatic vacuum packer of continuous type}

The automatic vacuum packer of continuous type was manufactured with a PLC control system(Fig. 8). An operating sequence for the developed vacuum packer is shown in Fig. 9. The maximum capacity of the vacuum packer was 6 pouches/min when $5 \mathrm{~kg}$ rice pouches were packed. The vacuum packer could be set according to vacuum time for renoving air, vibrating time for forming shape, and pouch position on the belt. Among the 108 pouches of rice products produced by the developed packer, 100 pouches were vacuum-packed successfully, and the other 8 pouches failed. The failure of vacuum packaging could be classified into type I and type II failures. The type I failure was caused by an inappropriate taping of the automatic vacuum packer. The unsuccessful sealing of a vinyl packer, cn the other hand, caused the type $\Pi$ failure. Among the failed 8 pouches, 6 pouches were categorized to the type I failure and the other 2 pouches to the type $\square$ failure. Through this experiment, it was observed that the success rate, type I failure rate, and type II failure rate were $92.6,5.5$, and $1.9 \%$, respectively.

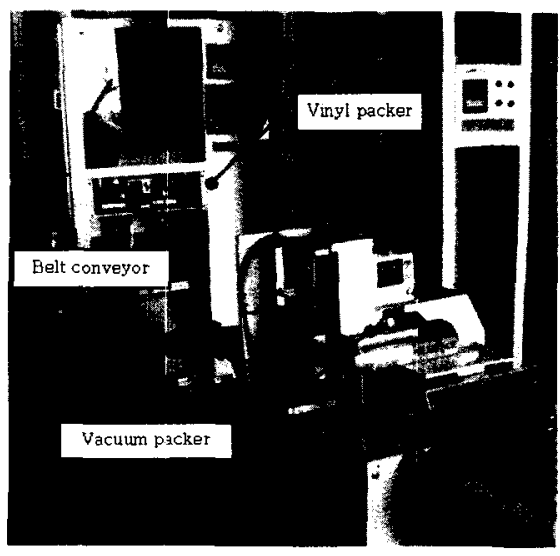

Fig. 8 The packing process using the developed automatic vacuum packer of continuous type.

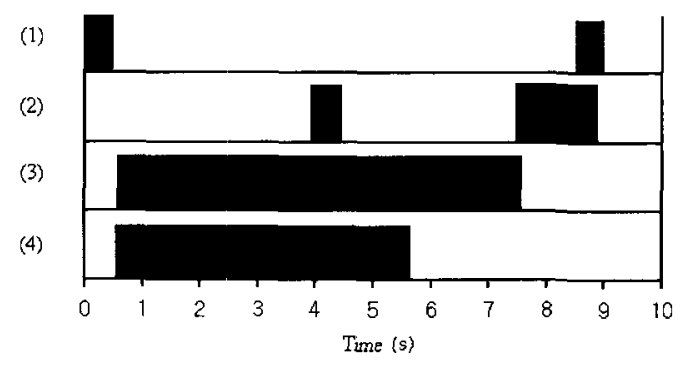

Fig. 9 The on-tme chart of operating sequence for an automatic vacuum packer ; (1) motor for driving the pressing board module ; (2) motor for driving the taping module; (3) vacuum pump ; (4) motor for driving the vibrating module. 
It was shown that the developed vacuum packer had a high success rate and processing capacity. Compared with some chemical methods such as oxygen scavengers that absorb the oxygen in a pouch by chemical reactions, the major advantages of the developed automatic vacuum packer were the low cost and food safety. A supplementary capability of controlled atmosphere packaging would also be added to the automatic developed vacuum packer for its future commercialization.

\section{B. Relationship between vacuum time and vacuum level}

The relationship between vacuum level and vacuum time at pouches of different sizes was investigated as shown in Fig. 10. During the beginning period of vacuum packaging, the air pressures in pouches increased to certain extent due to the pressing effect of the pressing board. The maximum air pressures in 2,3 , and $5 \mathrm{~kg}$ pouches were 802,804 , and 802 Torr, respectively. As the air removing process continued, the vacuum levels in the pouches decreased gradually. When the vacuum time was $11 \mathrm{~s}$, the vacuum level of a $5 \mathrm{~kg}$ pouch reached to the minimum value of 341 Torr. In the cases of 2 and $3 \mathrm{~kg}$ pouches, the minimum vacuum levels of 325 and 338 Torr reached in 6 and $8 \mathrm{~s}$, respectively. To reach the minimum vacuum level, the vacuum time need for $5 \mathrm{~kg}$ pouches was about 2 times and 1.5 times longer than that of $2 \mathrm{~kg}$ and $3 \mathrm{~kg}$ pouches. The relationship between vacuum level and vacuum time could provide assistance for the operators to determine

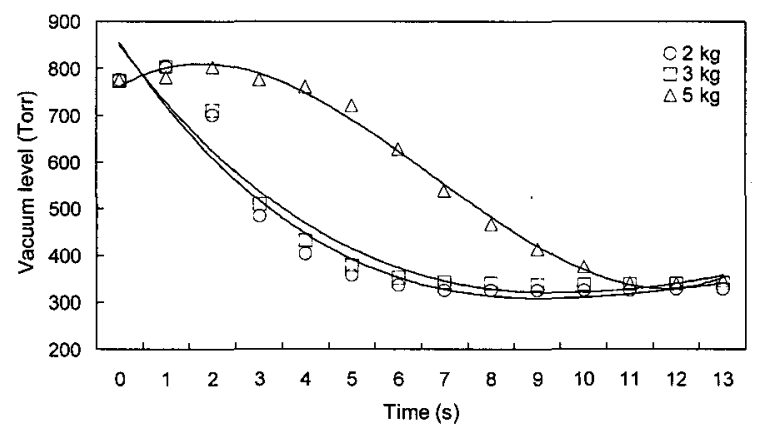

Fig. 10 Relationship between vacuum level and vacuum time at differently sized pouches. the necessary vacuum time quickly when rice products needed to be vacuum-packed at a certain vacuum level.

\section{Whiteness of white rice}

For both the vacuum-packed and the non-vacuum-packed rice, it was shown the longer the storage time was, the more the whiteness of milled rice decreased. The whiteness of the vacuum-packed and non-vacuum-packed rice decreased from the original whiteness of 35.9 to the values of 33.9 and 31.9, respectively, in 95 days(Fig. 11). However, the discoloration of non-vacuum-packed white rice with embryo was more serious, which was consistent with the results reported by Kim and Cho(1993). The decrease in whiteness was mainly due to the fact that the white rice with embryo packed in perforated pouches was exposed to outer oxygen, which accelerated the its aging process. In contrast, the whiteness of the vacuum-packed rice changed moderately. An equation for the whiteness of the vacuum-packed rice versus storage time was expressed as:

$$
\mathrm{W}_{\mathrm{v}}=-0.024 \mathrm{t}+36.13
$$

where $W_{v}$ is the whiteness of the vacuum-packed rice, $t$ is storage time(days), The coefficient of determination is 0.923. Another equation for the whiteness of the nonvacuum-packed versus storage time was presented as:

$$
\mathrm{W}_{\mathrm{n}}=-0.047 \mathrm{t}+35.98
$$

where $W_{n}$ is the whiteness of the non-vacuum-packed rice, $t$ is the storage time(days), the coefficient of determination is 0.968 .

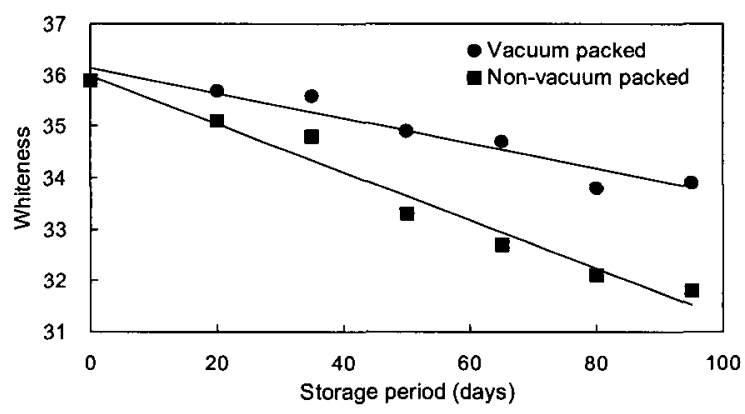

Fig. 11 The changes of whiteness of differently packed white rice with embryo. 


\section{Moisture content}

The changes of the moisture content of white rice with embryo are shown in Fig. 12. The moisture content of the vacuum-packed white rice with embryo decreased slowly during the experimental period, but the moisture content of the non-vacuum-packed rice decreased rapidly. The moisture content of the vacuum-packed rice decreased from $16.1 \%$ to $15.3 \%$, while the moisture content of the non-vacuum-packed rice quickly decreased from $16.1 \%$ to $14.8 \%$. The reason was due to the holes on perforated pouches in the case of non-vacuum-packed rice. The moisture of non-vacuum-packed rice was evaporated through the holes and its quality decreased. An equation for the change of moisture content of vacuum-packed rice versus storage time was

$$
\mathrm{M}_{\mathrm{v}}=-0.0078 \mathrm{t}+16.09
$$

where $M_{v}$ is the moisture content of the vacuum-packed rice(\%, w.b.), $t$ is the storage time(days), The coefficient of determination is 0.988 , The equation expressing the change of moisture content of the non-vacuum-packed rice versus storage time was

$$
\mathrm{M}_{\mathrm{n}}=-0.0145 \mathrm{t}+16.03
$$

where $M_{n}$ is the moisture content of the non-vacuumpacked rice(\%, w.b.), $\mathrm{t}$ is storage time(days), the coefficient of determination is 0.974 .

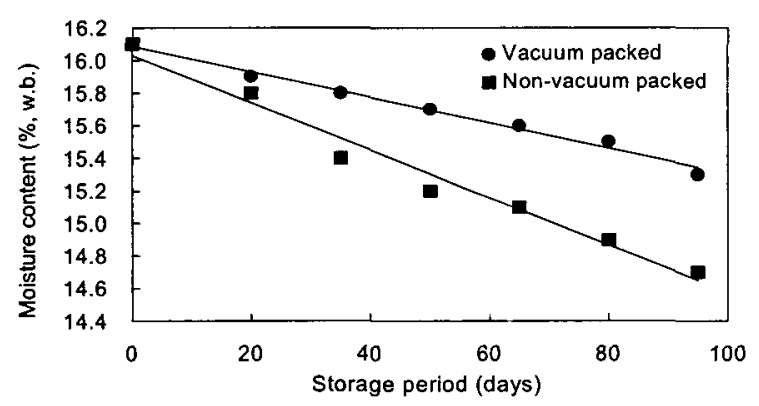

Fig. 12 The changes of moisture content (w.b.) of differently packed white rice with embryo.

\section{E. Peroxide value}

Unfavorable odors were sensed in the non-vacuumpacked white rice with embryo, and moulds were found on the surface of rice kernels in 45 days. The peroxide values versus storage time are shown in Fig. 13. The peroxide value of the vacuum-packed rice increased slightly, 1.89 meq $/ \mathrm{kg}$, over the entire experimental period. However, the peroxide value of the non-vacuum-packed rice increased to 10.22 meq $/ \mathrm{kg}$ rapidly until the $80^{\text {th }}$ day in storage and then dropped moderately to $6.67 \mathrm{meq} / \mathrm{kg}$. It was due to the fact that the peroxide generally reaches a peak and then decomposes into another material during the process of oxidation. This was consistent with the result reported by Barber(1972), who demonstrated that the storage of milled rice under poor conditions resulted in increased peroxide value of lipids. Although no further growing difference between the peroxide values was found, the preservation effects of vacuum packing on the rice quality were still continuing after 35 days. The shelf life of the vacuum-packed white rice with embryo was significantly $(\mathrm{P}<0.05)$ prolonged than that of non-vacuumpacked rice in terms of peroxide value. Two equations for the peroxide values of the vacuum-packed rice and the non-vacuum-packed rice versus storage time were:

$$
P_{n}=-0.3943 t^{2}+3.1186 t+3.75
$$

And

$P_{v}=-0.1193 t^{2}+1.1853 t+4.104$

Where $P_{v}$ and $P_{n}$ are the peroxide values of the vacuumpacked and of the non-vacuum-packed rice(meq $/ \mathrm{kg}$ ), respectively. $t$ is storage time(days), the coefficients of determination of the equations (6) and (7) are 0.907 and 0.982 , respectively

The peroxide value of vacuum-packed brown rice increased from $5.8 \mathrm{meq} / \mathrm{kg}$ to $7.11 \mathrm{meq} / \mathrm{kg}$, and then dropped gradually to $6.5 \mathrm{meq} / \mathrm{kg}$. Meanwhile, the peroxide of non-vacuum-packed brown increased quickly from 6.5 meq $/ \mathrm{kg}$ to $9.7 \mathrm{meq} / \mathrm{kg}_{\text {, }}$ and then decreased to $7.8 \mathrm{meq} / \mathrm{kg}$. The maximum peroxide values of the vacuum-packed and non-vacuum-packed brown rice, $7.1 \mathrm{meq} / \mathrm{kg}$ and $9.7 \mathrm{meq} / \mathrm{kg}$, were reached on the $50^{\text {th }}$ and $35^{\text {th }}$ days, respectively. Comparing the changes of the peroxide value of brown rice shown in Fig. 14, it was found the shelf life of the vacuum-packed brow rice was prolonged. 


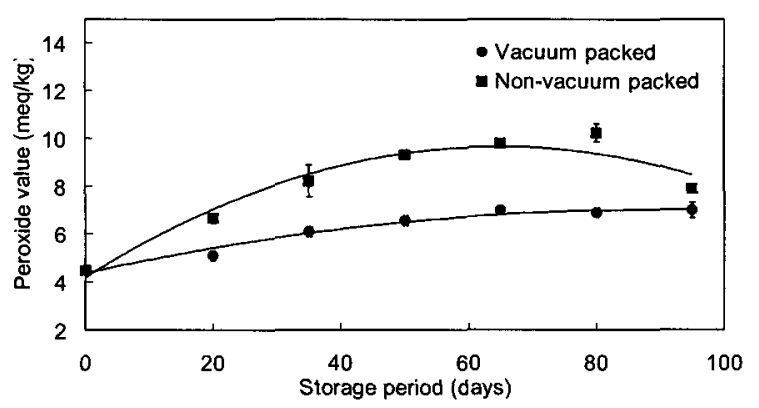

Fig. 13 The changes of peroxide values of differently packed white rice with embryo.

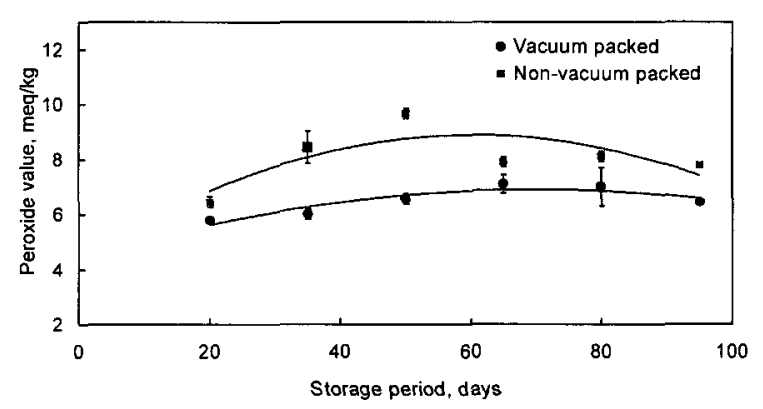

Fig. 14 The changes of peroxide values of differently packed brown rice.

\section{F. Acid value}

The relationship of the acid values versus storage time is shown in Fig. 15. The acid values of differently packed white rice with embryo increased consistently until the end of the storage experiment, but the acid value of the non-vacuum-packed white rice with embryo increased more rapidly than that of the vacuum-packed white rice with embryo. The maximum acid values of the vacuum-packed and non-vacuum-packed rice were 2.62 and $3.22 \mathrm{mg} / \mathrm{g}$, respectively. During the 3-month storage time, the acid values of the vacuum-packed and non-vacuum-packed rice increased by 0.71 and $0.98 \mathrm{mg} / \mathrm{g}$, respectively. The quality of the vacuum-packed white rice with embryo was significantly $(\mathrm{P}<0.05)$ preserved than that of non-vacuumpacked rice in terms of acid value. The change of the acid value of the vacuum-packed rice versus storage time was expressed as follows:

$$
A_{v}=-1 E-04 t^{2}+0.0211 t+1.8154
$$

where $A_{v}$ is the acid value of the vacuum-packed rice(mg/g), $t$ is storage time(days), the coefficient of determination $\left(R^{2}\right)$ is 0.8342 .

The change of the acid value of the non-vacuum-packed rice versus storage time was expressed as follows:

$$
\mathrm{A}_{\mathrm{n}}=-3 \mathrm{E}-05 \mathrm{t}^{2}+0.0142 \mathrm{t}+1.855
$$

where $A_{n}$ is the acid value of the non-vacuum-packed rice $(\mathrm{mg} / \mathrm{g}), \quad \mathrm{t}$ is storage time(days), the coefficient of determination $\left(\mathrm{R}^{2}\right)$ is 0.7357 .

The acid value of the vacuum-packed brown rice increased gradually from $1.93 \mathrm{mg} / \mathrm{g}$ to $2.47 \mathrm{mg} / \mathrm{g}$. However, the acid value of the non-vacuum-packed brown increased quickly from $2.26 \mathrm{mg} / \mathrm{g}$ to $2.98 \mathrm{mg} / \mathrm{g}$, and then decreased slightly to $2.88 \mathrm{mg} / \mathrm{g}$. The maximum acid values of the vacuum-packed and non-vacuum-packed brown rice, 2.47 $\mathrm{mg} / \mathrm{g}$ and $2.98 \mathrm{mg} / \mathrm{g}$, were reached on the $65^{\text {th }}$ and $50^{\text {th }}$ days, respectively. It showed the shelf life of the vacuum-packed brown rice was extended from the plots of acid values of brown rice shown in Fig. 16.

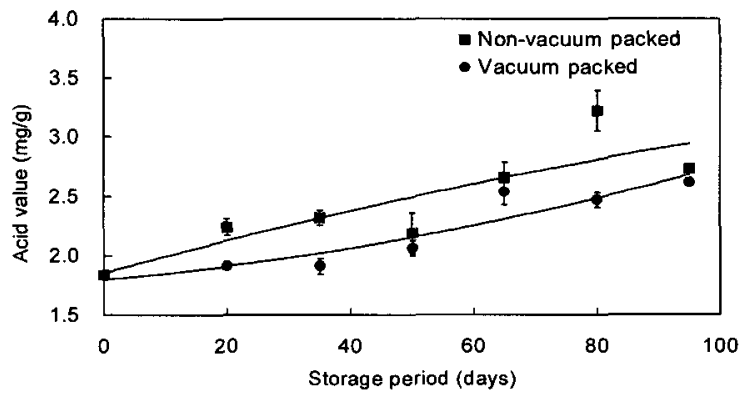

Fig. 15 The changes of acid values of differently packed white rice with embryo.

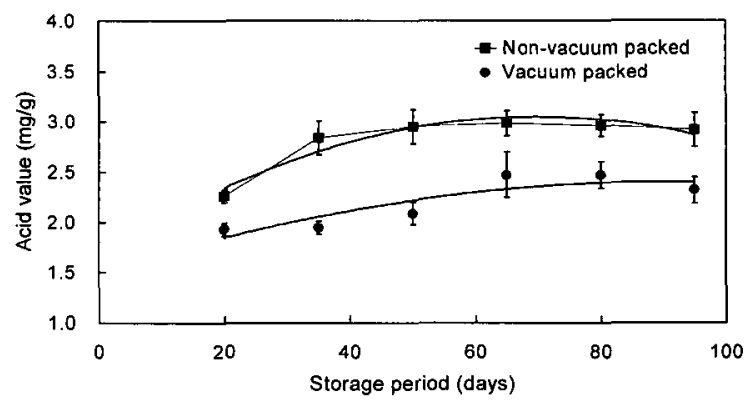

Fig. 16 The changes of acid values of differently packed brown rice. 


\section{G. Insect control}

The effect of vacuum packaging on insect control was analyzed by counting the number of the insects suffocated in each sample in 15 days after packing rice. It was found that all the insects in the pre-contaminated 5 samples were dead owing to lack of oxygen. It proved that vacuum packaging was very effective in insect control during the storage of market.

\section{CONCLUSIONS}

In this study, an automatic vacuum packer was especially developed to prolong the shelf life and to maintain the freshness of white rice with embryo. The success rate of the packaging tests was $92.6 \%$. The relationship between vacuum level and vacuum time at different pouch sizes was investigated for improving the productivity of the vacuum packer. It was found that it took $6,8,11 \mathrm{~s}$ to reach the minimum vacuum levels when packaging 2,3 , and $5 \mathrm{~kg}$ pouches. The whiteness of the non-vacuum- packed and vacuum-packed white rice with embryo decreased by 4 and 2 , respectively. The moisture content of the non-vacuumpacked and vacuum-packed white rice with embryo decreased by 1.3 and $0.8 \%$ (w.b.), respectively. The peroxide value of the non-vacuum-packed white rice with embryo increased by $3.45 \mathrm{meq} / \mathrm{kg}$ and then dropped moderately, but the peroxide value of the vacuum-packed white rice with embryo increased continuously by $1.89 \mathrm{meq} / \mathrm{kg}$. The acid values of the non-vacuum-packed and vacuum-packed white rice with embryo increased by 0.98 and $0.71 \mathrm{mg} / \mathrm{g}$, respectively. From the changes of whiteness, moisture content, and peroxide value of the vacuum-packed white rice with embryo, it was found the shelf life of the vacuum-packed white rice with embryo was increased.

The peroxide value and acid value of vacuum-packed brown rice increased slowly than the ones of non-vacuumpacked brown rice did. The maximum peroxide value and acid value of non-vacuum-packed brown rice increased by $2.6 \mathrm{meq} / \mathrm{kg}$ and $0.51 \mathrm{mg} / \mathrm{g}$ comparing with the ones of vacuum-packed brown rice. The comparison of the peroxide value and acid value of differently packed brown rice reconfirmed that the developed vacuum packer could be used to prolong the shelf life of white rice with embryo.

In addition to the above effects, the vacuum packaging also preserved rice quality by preventing the insect's development in the pouch.

\section{REFERENCES}

1. AOCS. 1973. Official and Tentative Method. American Oil Chemist Society, Illinois, U.S.A.

2. Barber, S. 1972. Milled rice and changes during ageing. In "Rice: Chemistry and Technology"(D. F. Houston, ed). American Association of Cereal Chemists, St. Paul, Minnesota, U.S.A.

3. Calderon, M. and R. Barkai-Golan. 1990. Food Preservation by Modified Atmospheres. CRC Press, Inc., England.

4. Erdman, G., G. N. Sandor and S. Kota. 2001. Mechanism Design Analysis and Synthesis. $4^{\text {th }}$ Edition, Prentice-Hall, Inc.

5. Hosokawa, A., T. Ban, I. Yokosawa, H. Yanase and S. Chikubu. 1995. Rice Post-Harvest Technology. THE Food Agency, Ministry of Agriculture, Forestry and Fisheries, Japan.

6. Houston, D. F. 1972. Rice Chemistry And Technology. American Association of Cereal Chemists, Inc.

7. Kim, S. K. and E. J. Cho. 1993. Effects of storage temperatures on the physicochemcial properties of milled rice. Journal of Korean Agricultural Chemical Society. 36(3):146-153.(In Korean)

8. Murcia, M. A., M. Martinez-Tomé, M. C. Nicolás and A. M. Vera. 2003. Extending the shelf-life and proximate composition stability of ready to eat foods in vacuum or modified atmosphere packaging. Food Microbiology, 20:671-679.

9. Yan, T. Y., J. H. Chung, J. U. Rhee and K. H. Lee. 2003. Development of a continuous auto vacuum packer using virtual prototyping - Kinetic Analysis -. Proc. of the KSAM 2003 winter conference, 8(1):118-124.(In Korean) 